\title{
An Analyis of Student's Academic Fraud Behavior
}

\author{
Muhsin, Kardoyo, Sandy Arief, Ahmad Nurkhin, Hengky Pramusinto \\ Faculty of Economics \\ Universitas Negeri Semarang (UNNES) \\ Semarang, Indonesia \\ muhsin@mail.unnes.ac.id
}

\begin{abstract}
This paper is intended to re-examine and analyze the student's academic fraud behavior in the perspective of fraud diamond. The research method used was quantitative research with the design of causality test to analyze the factors that influence the student's academic fraud behavior. The populations of this study were the students of Economics Education at Faculty of Economics in Universitas Negeri Semarang (UNNES)/State University of Semarang. The questionnaire was used to collect the data and developed from the fraud diamond concept. The data were analyzed using descriptive statistical analysis and multiple regression analysis. The results showed that: (1) the most frequently-committed academic fraud is wrongful cooperation to finish group assignments; and (2) based on the concept of fraud diamond, the pressure and rationalization are proven to have a significant effect on the students' academic fraud behavior. Meanwhile, the opportunity and capability are not proven to have any influence.
\end{abstract}

Keywords- academic fraud, fraud triangle, fraud diamond, pressure

\section{INTRODUCTION}

Academic dishonesty is a serious educational problem and a disturbing issue [1]. Academic fraud has been a never-ending phenomenon to solve. It can take any forms. Furthermore, it can happen at any time and be done by anyone, such as students or the others and for various reasons. Sagoro [2] suggested that some students are aware and some others are not that what they do is a fraud which can be sanctioned. High cumulative grade average, pride or merely dignity sometimes drive the students to commit the academic fraud. Hendricks (2004) defines the academic fraud (academic dishonesty) as numerous forms of behavior which give benefits for students improperly including cheating, plagiarism, stealing, and fabricating something related to the academic activity [2]. Academic fraud is defined as the use of public office for private gain in the academic field, especially regarding accreditation of courses and institutions, examinations for access and for transfers between institutions, certificates and diplomas, university/college research and publications [3].

From the researcher's observation, it is found that the academic fraud is also done by the students of Economics Education Department of Faculty of Economics, UNNES. The frequently occurring academic frauds are (1) omitted reference of sources in the quotes made in writing final projects, (2) cooperation for mid-term or final term tests (when they are required to do it independently), (3) cheating during examination, and (4) no involvement in group assignment completion. These phenomena were also revealed in the research conducted by [4]. Nevertheless, the academic frauds committed by the students at FE UNNES are relatively low.

Several approaches were used to detect the determinant factors of the academic fraud behavior committed by students, including fraud triangle concept. This concept has long been known in analyzing the factors influencing financial fraud behavior. The fraud triangle concept was introduced by [5] a criminologist, by proposing the argumentation that there must be reasons for someone to do something (including fraud) namely pressure, opportunity and rationalization [6]. The fraud triangle elements consist of pressure, opportunity, and rationalization [7]. The first side of the fraud triangle represents a pressure or motive to commit the fraudulent act, the second side represents a perceived opportunity, and the third side stands for rationalisation [8]. One study showed that opportunity is found to have positive and significant influence on the employee's fraud [9].

A study found that there is positive influence of academic pressure, cheating opportunity, and cheating rationalization on the student's academic fraud behavior [10]. Another study showed that pressure and rationalization have significant influence on the academic fraud behavior of bachelor-degree accounting students of Undiksha, while opportunity is not found to have significant influence on academic fraud behavior [11].

The fraud diamond concept is later developed to understand other factors which influence fraud behavior. The fraud triangle concept can be developed to prevent and detect fraud behavior by adding one element, namely capability. Thus, it is then known as fraud diamond, consisting of incentive (pressure), opportunity, rationalization, and capability [12]. The researchers who have applied the fraud diamond concept proved it that opportunity, rationalization and capability have positive, significant impact on the academic fraud behavior, and pressure has no effect [13]. Another researcher found that opportunity, rationalization and capability have some influences on student's academic fraud behavior. In regard to pressure, it is found to have no impact on student's academic fraud behavior [14]. Meanwhile, [15] found quite different result. They only found positive and significant effect of pressure on the academic behavior. Furthermore, the other elements of fraud diamond (opportunity, rationalization, and capability) are not found to be able to detect the academic fraud behavior. They also used gone theory and successfully found that greed, need, and exposure can influence student's academic fraud behavior. 
The newly developed concept is fraud pentagon which tries to better capture the factors influencing fraud behavior to occur. Tugas [16] proposed the fifth element in the fraud pentagon concept, namely external regulatory influence. If the external regulatory influence is weak, it is then highly likely for fraud to occur. G Tessa \& Harto [7] explained that the updated theory which covers deeper the triggering factors of fraud is the Crowe's fraud pentagon theory. This theory was presented by [17]. Fraud pentagon theory is an extended version of fraud triangle theory presented by Cressey earlier. This theory adds two more elements fraud namely competence and arrogance. The competence described in this fraud pentagon theory bears the same meaning as capability previously explained in fraud diamond theory [12]. Competence/capability means an employee's capability to ignore internal control, develop a concealment strategy, and control the social situation for his/her own personal benefits. Meanwhile, arrogance is the superiority attitude for having certain rights and the feeling that the internal control or policy of the company are not applicable to oneself [7]. Tugas [16] also proposed fraud pentagon concept by adding the external regulatory influence. Fraud will never exist if the regulators can apply the rules ruthlessly so that they will be able to manage the organization members to comply with them.

The application of fraud diamond theory in detecting the academic fraud has varied findings. It becomes interesting then to conduct another research. This research tries to re-prove the determinants of the academic fraud behavior in the perspectives of the three concepts described earlier (fraud triangle and fraud diamond). It is expected that more comprehensive results will be obtained regarding the phenomenon of the academic fraud behavior committed by students and its determinant factors.

\section{HYPOTHESIS}

Some theories try to understand the factors influencing the individual's fraud behavior, including such concepts as fraud triangle [5], fraud diamond [12] and fraud pentagon [16], [17]. These three theories are developed from financial statements fraud which is later adapted to education field within the concept of academic fraud. There are three elements in fraud triangle concept, namely opportunity, pressure, and rationalization. Furthermore, an element is added to make the fraud diamond concept, namely capability. In the fraud pentagon concept, another element is added further, namely arrogance.

Pressure is defined as a strong urge from within students themselves and outside them to be a high-achiever or the other purposes by doing anything. The pressure influences students a lot to behave unfairly during their learning process and examination. This means if the pressure is huge, it is highly likely that academic fraud behavior will be done bythese students. Some researchers have successfully proved it [10], [11], [15] However, some others fail to prove that pressure has positive influence on academic fraud [13], [14].
Opportunity refers to the opportunity intentionally or accidentally occurring under classroom situation which forces a student to commit any fraud behavior. Therefore, the opportunity is expected to have positive influence on student's academic fraud behavior. The more opportunities are available, the greater the chance of academic fraud to occur. The research results showed that opportunity is found to have some influence on the academic fraud behavior [10], [13], [14] Yet, the other studies fail to find any positive influence of opportunity on any fraud [11], [15].

Rationalization is defined as a strong reason which underlies a student to justify his/her cheating. It means the more justifications he/she has to what he/she does, the greater the chance of the academic fraud behavior to occur. Hence, it can be said rationalization has positive influence on the academic fraud behavior [10], [13], [14].

The next element is capability which can be defined as student's capability to ignore the internal control, develop a concealment strategy, and control the social situation for his/her own personal benefits. The students who are capable of controlling themselves and their surrounding have a greater tendency to commit a fraud. They will be calmly committing the action. The students who are less capable of controlling themselves will have less courage to commit any fraud during the examination. Nursani \& Irianto [13] and Pratama [14] have successfully found the positive influence of capability on the academic fraud behavior. Meanwhile, [15] failed to prove this positive influence.The above description can be summarized in Fig.1.

Based on the above description, some research hypotheses below can be proposed;

- H1: Pressure has positive influence on the academic fraud behavior.

- H2: Opportunity has positive impact on the academic fraud behavior.

- H3: Rationalization has positive effect on the academic fraud behavior.

- H4: Capability has positive influence on the academic fraud behavior.

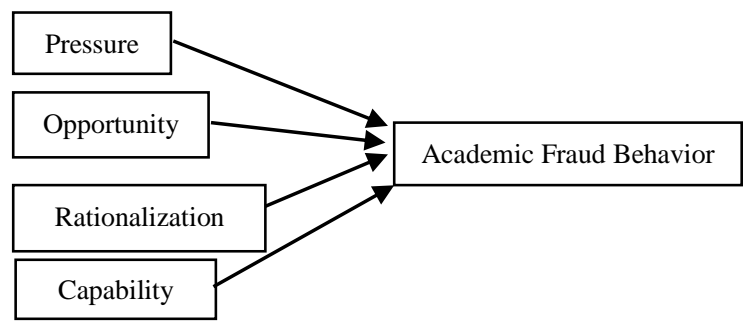

Fig. 1. Empirical framework 


\section{RESEARCH METHOD}

This research used a quantitative method with a causality design that is a research attempting to find out the causes and consequences. This research aimed at investigating the determinants of student's academic fraud behavior in the fraud triangle, fraud diamond, and fraud pentagon perspectives.

The population in this research was the students of Economics Education Department of Faculty of Economics (FE), Universitas Negeri Semarang (UNNES)/State University of Semarang consisting of the students majoring in Office Administration Education, Accounting Education and Education of Cooperatives. The samples were taken using purposive sampling method. The criteria used were enrolled to the Economics Educations of FE UNNES class 2014, who were thought to better understand the academic fraud behavior than those of classes 2015 and 2016. Thereby, the sample in this research amounted to 399 students.

The dependent variable in this research was academic fraud behavior. Meanwhile, the independent variables in this research were pressure, opportunity, rationalization, and capability. These independent variables were developed from the fraud triangle and fraud diamond concepts.

The data in this research were obtained using questionnaire. The questionnaire was developed from several previous studies to capture the research variables more accurately. The developed questionnaire has been tested for its validity and reliability. The instrument validity and reliability tests utilized SPSS. The data were analyzed using descriptive and inferential statistical analysis. The descriptive statistical analysis was employed to describe the research variables in the form of mean, minimum, maximum, and standard deviation. The inferential statistical analysis used here was multiple regression analysis to test the proposed hypotheses. The hypothesis tests were conducted using the following two regression equations.

$$
\begin{aligned}
& A F B 1=a+\text { b1 pressure }+ \text { b2opportunity }+ \text { b3rationalization } \\
& \text { AFB2 }=a+\text { blpressure }+ \text { b2opportunity }+ \text { b3rationalization }+
\end{aligned}
$$
b4capability

\section{Description:}

AFB1 = academic fraud behaviour model 1

AFB2= academic fraud behaviour model 2

$A=$ constant

$b 1, b 2, b 3, b 4=$ regression coefficient

TABLE I. DESCRIPTION OF STUDENT'S ACADEMIC FRAUD BEHAVIOR, DEPARTMENT OF ECONOMIC EDUCATION, FACULTY OF ECONOMICS UNNES

\begin{tabular}{|l|l|l|l|}
\hline No. & Indicator & Score & Meaning \\
\hline 1 & $\begin{array}{l}\text { Academic fraud in individual } \\
\text { assignment }\end{array}$ & 1.90 & Very rarely \\
\hline 2 & Academic fraud in group assignment & 1.56 & Very rarely \\
\hline 3 & Academic fraud during examination & 1.80 & Very rarely \\
\hline & Mean & 1.76 & Very rarely \\
\hline
\end{tabular}

${ }^{\text {a. }}$ Source: Processed data, 2017

\section{RESULT AND DISCUSSION}

The respondents in this research amounted to 399 students of Economics Education Department of FE UNNES. The completed instruments which could proceed thedata analysis were 206. Therefore, the response rate was 52\%. The description results of the variable of the academic fraud of the students of Economics Education Department of FE UNNES can be seen in Table 1 . Table 1 shows that the student's academic fraud behavior is classified as very rarely. The frequently-committed academic fraud is the one done during the group assignment completion. One of its forms is inactive involvement in completing the group assignment.

The result of hypothesis testing can be seen in Table 2 . In the first model (within fraud triangle perspective), it is found that all independent variables were proved to have positive and significant influence on the academic fraud behavior. This case shows that fraud triangle concept could be proved significantly. In the second model (within fraud diamond perspective), only pressure and rationalization variables that were proven to have positive and significant impact at a significance rate of $5 \%$. Meanwhile, opportunity and capability variables were found to have no positive and significant effect. Therefore, this research failed to prove the fraud diamond concept in detecting the factors influencing the student's academic fraud behavior.

The findings of this research confirmed the previous findings [10], [11]. Schuchter \& Levi [5] argued that although opportunity is necessary but it is not a sufficient condition for 'upperworld' criminal offences; our respondents regard the perceived pressures they experienced as salient. Mavisakalyan $\&$ Meinecke [18] found that incentives to commit the academic fraud are strong and point towards the potentially damaging consequences of the academic fraud in broader settings. This is despite the fact that [11] failed to prove that opportunity has some influences on the academic fraud. Ligi \& Trasberg [19] found that students commit academic fraud mainly because of individual reasons such as not being able to memorize the necessary amount of material and that students are not very well aware of the regulations concerning the academic dishonesty.

The research results show that the fraud triangle dimensions could be proven in this research. The pressure, opportunity, and rationalization variables were proven to have positive and significant influence on the academic fraud behavior of Economics Education Department students in FE UNNES. It means that the bigger the pressure a student experience, the more likely they will commit academic fraud. The fraud can take many forms such as non-involvement in group assignment, dishonesty in completing individual assignments and plagiarism. The opportunity to cheat also causes students to commit the academic fraud. The students are also influenced by the rationalization in committing academic fraud. In addition, the influences of pressure, opportunity, and rationalization were fairly strong at $78 \%$. This finding confirmed the previous findings.

The fraud triangle is the most popular model of explaining the nature of fraud. Different authors have created new types of the fraud models. Fraud has a very diverse nature and that is why the definitions vary a lot. 
TABLE II. SUMMARY OF HYPOTHESIS TESTING RESUlTS

\begin{tabular}{|c|c|c|c|c|c|}
\hline \multicolumn{3}{|l|}{ MODEL 1} & \multicolumn{3}{|l|}{ MODEL 2} \\
\hline Variable & $\begin{array}{l}\mathrm{t} \text { test } \\
\text { (Sig.) }\end{array}$ & $\begin{array}{l}\text { F test } \\
\text { (Sig.) }\end{array}$ & Variable & $\begin{array}{l}t \text { test } \\
\text { (Sig.) }\end{array}$ & $\begin{array}{l}\text { F test } \\
\text { (Sig.) }\end{array}$ \\
\hline (Constant) & $\begin{array}{l}-2,992 \\
(.003)\end{array}$ & \multirow[t]{5}{*}{$\begin{array}{l}243,392 \\
(.000)\end{array}$} & (Constant) & $\begin{array}{l}-3.286 \\
(.001)\end{array}$ & $\begin{array}{l}186.012 \\
(0.000\end{array}$ \\
\hline Pressure & $\begin{array}{l}5.612 \\
(0.000)\end{array}$ & & Pressure & $\begin{array}{l}5.909 \\
(.000)\end{array}$ & \\
\hline Opportunity & $\begin{array}{l}2.695 \\
(0.008)\end{array}$ & & Opportunity & $\begin{array}{l}1.795 \\
(.074)\end{array}$ & \\
\hline \multirow[t]{2}{*}{ Rasionalization } & $\begin{array}{l}6.243 \\
(0.000)\end{array}$ & & Rasionalization & $\begin{array}{l}5.113 \\
(.000)\end{array}$ & \\
\hline & & & Capability & $\begin{array}{l}1.947 \\
(.053)\end{array}$ & \\
\hline Adjusted $\mathrm{R}^{2}$ & & 0,780 & Adjusted $\mathrm{R}^{2}$ & & 0,783 \\
\hline
\end{tabular}

This is one of the reasons why there are a lot of different opinions. For the same reason different fraud models have been built up. For periodization he composed the timeline from 1950 to 2016 [20]. Fraud diamond is the developed concept from fraud triangle. It wants to find a new factor that affects the fraud. Best understanding about the determinant of academic fraud behavior is very important to do.

This research, however, failed to prove the fraud diamond concept for only pressure and rationalization variables that were found to have positive and significant influence on the student's academic fraud behavior. Meanwhile, the opportunity and capability variables were only be proven to have positive and significant influence at an error margin of $10 \%$. Their simultaneous influence was fairly strong, i.e. $78.3 \%$. It can be understood that the students will not be able to commit any fraud even if an opportunity is available right in front of their eyes and they can do the fraud. Students will only commit fraud if they are under pressure and have the reasons to commit the fraud. Besides, the pressure variable is highly dominant in influencing the student's academic fraud behavior. The strongest pressure that students experience comes from lecturers, peers and parents. The students will look for rationalization for this pressure. Eventually, the students will commit the academic fraud.

This research results have not entirely confirmed the previous studies' results. The fraud diamond dimensions were proven to have positive and significant influence on the academic fraud [13]. Meanwhile, in [15] only pressure dimension that was proven to have positive and significant impact on the academic fraud. Meanwhile, in [14] only pressure dimension which was found to have no positive and significant effect on the academic fraud behavior. Santoso and Surenggono [21] found that pressure and capability of fraud diamond were proven have positive and significant influence to the fraud. He used fraud diamond concept to predict the financial statement fraud. Conclusion

The academic fraud behavior of Economics Education Department students in FE UNNES is relatively low. They very rarely commit the academic fraud behavior. The most frequently-committed academic fraud is the one during group assignment. This research successfully proved the fraud triangle concept, where all dimensions were proven to have positive and significant influence on the student's academic fraud behavior. However, this research failed to prove the fraud diamond concept thoroughly. Only pressure and rationalization dimensions that were proven to have some impacts on the academic fraud behavior, with the pressure dimension having highly strong effect on fraud. The fraud pentagon concept can be proposed to understand the academic fraud behavior within another perspective.

\section{REFERENCES}

[1] C. K. H. C. K. Kassim, N. E. M. Nasir, and S. Ahmad, "Academic Dishonesty of Accounting Students at Higher Learning Institutions," Mediterr. J. Soc. Sci., vol. 6, no. 4, p. 702, 2015.

[2] E. M. Sagoro, "Pensinergian Mahasiswa, Dosen, dan Lembaga dalam Pencegahan Kecurangan Akademik Mahasiswa Akuntansi.," $J$. Pendidik. Akunt. Indones., vol. 11, no. 2, pp. 54-67, 2013.

[3] J. Hallak and M. Poisson, "Academic fraud, accreditation and quality assurance: learning from the past and challenges for the future," vol. 13, no. 58, pp. 109-123, 2007.

[4] M. Fuadi, "Determinan Kecurangan Akademik Pada Mahasiswa Fakultas Ekonomi Universitas Negeri Semarang Dengan Konsep Fraud Triangle," Universitas Negeri Semarang, 2016.

[5] A. Schuchter and M. Levi, "The fraud triangle revisited," Secur. J., vol. 29, no. 2, pp. 107-121, 2016.

[6] N. Mansor, "Fraud Triangle Theory and Fraud Diamond Theory. Understanding the Convergent and Divergent For Future Research," Int. J. Acad. Res. Accounting, Financ. Manag. Sci., vol. 5, no. 4, pp. 38-45, 2015.

[7] C. G Tessa and P. Harto, "Fraudulent Financial Reporting: Pengujian Teori Fraud Pentagon Pada Sektor Keuangan Dan Perbankan Di Indonesia," pp. 1-21, 2016.

[8] J. T. Wells, Corporate fraud handbook: Prevention and detection. John Wiley \& Sons., 2011.

[9] K. Kusumantoro, A. Nurkhin, H. Mukhibad, and K. Kiswanto, "Determinants of Fraud Based on Islamic Paradigm: Case Study in Islamic Financial Services Cooperatives," Int. J. Comput. Internet Manag., vol. 24, no. 3, pp. 68-71, 2016.

[10] D. D. Pamungkas, "Pengaruh Faktor-Faktor dalam Dimensi Fraud Triangle terhadap Perilaku Kecurangan Akademik Siswa Kelas Xi Akuntansi Smk Negeri 1 Tempel Tahun Ajaran 2014/2015," Fakultas Ekonomi UNY, 2015.

[11] N. Apriani, S. E. Edy Sujana, N. L. G. E. Sulindawati, and M. SE Ak, "Pengaruh Pressure, Opportunity, Dan Rationalization Terhadap Perilaku Kecurangan Akademik," JIMAT (Jurnal Ilm. Mhs. Akuntansi), vol. 7, no. 1, 2017.

[12] D. T. Wolfe and D. R. Hermanson, "The fraud diamond: Considering the four elements of fraud," CPA J., vol. 74, no. 12, pp. 38-42, 2004.

[13] R. Nursani and G. Irianto, "Perilaku Kecurangan Akademik Mahasiswa: Dimensi Fraud Diamond," J. Ilm. Mhs. FEB UB, vol. 2, no. 2, pp. 1-21, 2013.

[14] R. Y. S. Pratama, "Analisis Dimensi Fraud Diamond Dan Gone Theory Terhadap Academic Fraud," Universitas Muhammadiyah Surakarta, 2017.

[15] M. Zaini, A. Carolina, and A. R. Setiawan, "Analisis Pengaruh Fraud Diamond dan Gone Theory Terhadap Academic Fraud (Studi Kasus Mahasiswa Akuntansi Se-Madura)," pp. 1-20, 2015.

[16] F. C. Tugas, "Exploring a new element of fraud: A study on selected financial accounting fraud cases in the world," Am. Int. J. Contemp. Res., vol. 2, no. 6, pp. 112-121, 2012.

[17] H. Crowe, "Why the Fraud Triangle is No Longer Enough," 2011.

[18] A. Mavisakalyan and J. Meinecke, "The labor market return to academic fraud," Eur. Econ. Rev., vol. 82, pp. 212-23, 2016.

[19] L. Magnus and T. Karmen, "University students' reasons for Committing academic fraud and knowledge about regulations: a qualitative interview study," Educ. Stud., vol. 2014, no. 4, pp. 1-21, 2014. 
[20] M. Vassiljev and L. Alver, "Concept And Periodisation Of Fraud Models: Theoretical Review," 5th Int. Conf. Accounting, Audit. Tax. (ICAAT 2016), pp. 0473-0480, 2016.
[21] N. T. Santoso, "Predicting Financial Statement Fraud with Fraud Diamond Model of Manufacturing Companies Listed in Indonesia," State-of-the-Art Theor. Empir. Evid., vol. 15, pp. 151-163, 2017. 